\title{
The Effects of Innovation and Market Orientation on Customer Service for Customs Clearance Firms in the International Logistics Processes: the Analyses of Direct, Indirect, Causal Effects and Moderating Effects between Variables
}

\author{
Heesung Bae*, Yangkee Lee**, and Wooyoung Lee***
}

\begin{abstract}
This study has two objectives. The first aim is to ascertain whether innovation and market orientation have direct, indirect, and causal effects on customer service. The second objective is to ascertain whether market orientation has a moderating effect on the relationship between innovation and customer service. This research follows three distinct methodologies. The first approach uses Cronbach's alpha coefficient in order to check reliability while an exploratory factor analysis and a confirmatory factory analysis ascertain validity. The second method uses the analysis of structural equation models to test a causal link between variables. The third methodology uses a moderated regression analysis to verify the moderating effects. As our analysis results show, intelligence generation and intelligence dissemination have a moderating effect on the relationship between innovation and flexibility. These results can be interpreted as follows: firstly, customs clearance firms can provide superior service to customers if they strive to understand customer needs and provide them with flexible service at the same time. Secondly, these firms can enhance their flexibility of service in all departments though innovation and information sharing acquired from the market.
\end{abstract}

Keywords: innovation, market orientation, customer service, moderating effect

Submisson Date : 02/01/2012 Revision Date : 03/14/2012 Acceptance Date : 03/14/2012

* First Author, Ph.D student, Business School, University of Hull, UK.

E-mail : h.s.bae@2009.hull.ac.uk

${ }^{* *}$ Co-Author, Research professor, Pusan National University, Korea.

E-mail : yangkee21@pusan.ac.kr

*** Corresponding Author, Associate professor, Kyungsung University, Korea.

E-mail : wyrhee@ks.ac.kr 


\section{Introduction}

Ports are important nodes of international logistics. The logistics service in ports is varied and may include international transportation services, loading/unloading, storage, bonded transportation services, and clearance services, among others. Delays attributed to the logistical flow in ports can be due to inefficient logistical processes resulting from the restriction in the flow of information and the flow of goods. Delays in the customs clearance process of goods can be the cause of major delays throughout the entire logistical process.

Clearance in the logistical process doesn't appear to be a problem at first glance because participants cooperate and firms share their logistical information. However, fierce competition between customs clearance firms and adverse cost competition reveal a problem with logistics service providers that are concerned to port logistics. The causes of these problems are twofold: first, there are too many customs clearance firms, forwarders, and other service providers competing with one another in the Korean port logistics processes; secondly, the fierce competition among customs clearance firms is compounded by cost leadership rather than by service differentiation. Consequently, customs clearance firms have been experiencing extremely low profits. Therefore, this study on customs clearance firms as service providers in the international logistics process attempts to provide the basis for research by investigating the efficiency and the effectiveness of the services provided by port logistics service providers.

Customs clearance firms face keen competition and should establish efficient clearance processes in order to maintain a sustainable competitive advantage and improve their domestic environment. These firms can provide customers with low-cost, one-stop services. They can also reduce costs and improve services through the proper use of these clearance processes. However, many customs clearance firms do not have knowledge regarding the importance of process improvements through innovation; even if they recognize their importance, they cannot effectively change their internal processes because of limitations, such as human and material resources.

Innovation comes from work standardization, process improvement, and collaboration among departments. Larson (1994) and Daugherty et al. (1996) examined the internal innovation within firms' and focused their research on logistics integration. Stank et al. (1999), Ellinger (2000), and Mollenkopf et al. (2000) conducted their research on the cross-collaboration between marketing, logistics, and other departments; and Grawe et al.(2009) ascertained that collaboration has a positive effect on performance. However, these researchers overlooked several external factors, such as the characteristics which are 
found across firms, the use of information regarding the market, and customer needs because of their excessive focus on the inner workings of the firms.

Market orientation can be explained as follows: firms strive to foresee changes in the market and to respond to their customers' requirements in order to enjoy a competitive advantage (Kohli and Jaworski, 1990). Kohli and Jaworski (1990) and Naver and Slater (1990) gave definitions of market orientation and a number of researchers carried out empirical tests which use their definitions (Agarwal et al., 2003; Caruana et al., 1997; Esteban et al., 2002; Jaw et al., 2010; Lancaster and Velden, 2004; Panayides, 2004). However, they all overlooked the viewpoint of innovation related to the efficiency of internal processes and the collaboration among departments because of their excessive focus on external factors.

Customs clearance firms involved in the international logistics process perform the clearance of goods and accessory services. In particular, these firms provide shippers and consignees with services related to the clearance of Korean Customs Laws and with additional services, such as inspections, bonded transportation, and the consolidation of goods for their customers. These firms can act as the customs broker, an incorporated customs clearance firm, or a clearance service provider by providing customers with various services and by following the international logistics process. However, they have not mastered the process because of minimal size and their numerous management problems. In this situation, this research focuses on their development methods. Therefore, this research suggests strategic methods for firms by ascertaining innovation and market orientation and by testing whether innovation and market orientation have a direct, indirect, or causal effect on customer service. According to the results, this research can also propose theoretical and practical implications by checking the moderating effects between variables.

\section{Literature review}

This research examines prior research with two viewpoints in mind: in the first one, this review suggests that customs clearance firms need to implement supply chain management (SCM) by explaining the relationship between logistics and SCM; in the second, this review ascertains the relationship between variables, such as innovation, market orientation, and customer service. 


\subsection{The relationship between logistics and SCM}

The concept of SCM begins with an environment change in increasing manufacturing costs, a shorter product life cycle, the diversification of customer needs, and economic globalization. Given these circumstances, recent research needs to focus on SCM and not merely on the logistics processes of each individual firm.

Supply chains can be defined as the consecutive processes which achieve joint goals between various supply chain participants, such as suppliers, manufacturers, wholesalers, and retailers. Supply chains are involved in the following processes: the acquirement of raw materials, the input of materials into the manufacturing processes, and the final delivery of goods to customers (Beamon, 1998). The supply chain process has the characteristics of the downstream flow of raw materials and the upstream flow of information (Gunasekaran et al., 2001).

Logistics can be defined as the processes to plan, execute, and oversee the efficient and effective transportation and custody of goods, services, and information from the place of origin to the place of consumption. In this situation, logistics activities may include all activities which are related to logistics, such as customer service, prediction of demand, information concerned with distribution, the control of goods in stock, managing transportation, processing orders, providing parts and accessories, the location of factories and warehouses, packing, processing returned goods, recycling, waste management, transportation, loading/unloading, and custody issues (Bowersox et al., 2002).

Logistics in supply chains play an important role as a mediator in promoting the physical distribution of goods from the place of origin to the place of final consumption. These consecutive processes create value which conforms to the time and place of goods. Supply chains could be integrated with logistics, which provide connections and simultaneity in a whole process for an effective SCM. Therefore, supply chains are inclusive of the concept of logistics. SCM includes the integration of information systems and the adjustments of plans and activities between firms which are not included in the logistical activities.

Supply chains include the transmission of information and the delivery of goods between suppliers, manufacturers, customers, and service providers in addition to the integration of the internal activities of each participant. SCM includes a confirmation of the participants' needs, the design of the goods and services which correspond to the needs, and the other processes connected with the participants' activities and processes. There is a degree of overlap and confusion sometimes in the definitions of logistics and SCM. On the one hand, logistics have an internal viewpoint of firms, even though they manage the physical flow of goods between suppliers and customers from the viewpoint of a focal firm; 
on the other hand, SCM includes the physical flow, the management of customers' orders, manufacturing processes, and the flow of information needed to integrate all participants' activities. If firms are to achieve their supply-chain goals, these processes are needed in order to remove the overlaps and inefficiencies in the supply chain by enhancing the interactions and collaborations between the participants.

In regards to SCM, a supply-chain leader should manage and adjust the flow of goods and information throughout the supply chain. Suppliers, manufacturers, and customers as supply chain participants need efficiency throughout the entire supply chain, but they must also focus on their internal needs. In this situation, they need a mediator, should opportunism regarding their supply chain processes give rise to a conflict of interests between them. Logistics firms could perform the role of a supply chain leader. Logistical service providers, as customs clearance firms and carriers, could efficiently manage the supply chain processes for the supply chain participants through their expert logistical services. Therefore, these providers could structure the most suitable processes by adjusting and managing the supply chains for their customers. In this regard, these firms could play the role of a supply-chain leader.

\subsection{Innovation and market orientation}

Innovation is defined as the ability to innovate internal processes in order to fulfill customer needs (Bowersox et al., 2002). Market orientation means that firms strive to estimate an environmental change and to respond to customer needs better than their competitors in order to benefit from high profits and a sustainable competitive advantage (Kohli and Jaworski, 1990).

Firms can redevelop their internal processes through work standardization, process improvement, and collaboration among departments. Consequently, they can also remove overlaps and inefficiencies throughout the whole process. If firms have an efficient internal process, they need to make efficient use of external information (Narasimhan and Kim, 2001). Therefore, the more innovative a firm is, the better it uses the market information.

Market orientation goes through the following stages: intelligence generation, intelligence dissemination, and responsiveness. Firms can enjoy increased performance over their competitors if they can collect market information and make effective use of it internally. This property means that market information has an effect on firms' internal processes if they can make efficient internal processes and can structure high-quality customer service. Therefore, firms that have a high level of market orientation can acquire an accurate grasp of their customers' needs by acquiring market information and by 
changing their internal processes in order to disseminate information inside of the firms. These firms can restructure their processes following this change and can thus provide high-quality services to their customers.

\subsection{Innovation and customer service}

Effective relationships among departments with regards to innovation should also include the knowledge of the staff that works in other departments. This relationship should be valuable, fair, productive, and satisfactory. The more inter-dependent departments become, the more their success depends on the relationship among them (Ellinger et al., 2000). In this situation, the effectiveness of the relationship between departments is based on the awareness of mutual collaboration. Therefore, the effectiveness should enhance the collaboration. According to Stank et al. (1999), innovative processes within firms have a positive influence on customer service. Innovative processes have an effect on various outputs from organizations, including decreasing the work hours, developing new products, and knowing the customers' value.

Collaboration at the operational level requires that some changes be made to existing business practices, such as the exchange of information between departments. Each department, through collaboration, shares information with the others regarding future plans, predictions, and procurement between departments. Under these circumstances, a collaborative attitude between departments can be the root of superior customer service because the departments are sharing information about customer needs (Storey and Hull, 2010).

Collaboration has various benefits: joint work, mutual understanding of different viewpoints, the sharing of information and resources, achieving goals and enjoying the high performance which the company benefits from. Therefore, innovation can enhance customer service because it responds notably well to customer needs once a firm has achieved an internal efficiency.

\subsection{Market orientation and customer service}

The adjustment of resources between departments for creating superior customer value seems to show that market orientation has become one of the necessary factors in order for firms to maximize long-term benefits. In this regard, superior customer value is an index which is related to market share and competitive advantage and can be increased by achieving long-term goals, such as increasing profits, development, and the overall value of 
a firm.

Market orientation is a key factor in developing a competitive advantage because it is strongly related to and takes advantage of the position of the firms in the market. In this situation, the advantage consists of strategic orientation, such as the cost leadership strategy in stressing internal factors and the differentiation strategy in stressing external factors. Therefore, market orientation should serve as a guide for a firm's strategy, and performance can differ according to the firm's strategy. According to the research of Naver and Slater (1990) on the relationship between market orientation and competitive strategy, market orientation has a stronger correlation to the differentiation strategy than it does to the cost leadership strategy.

Market-oriented firms understand that service is an exchange factor which is necessary in order for the satisfaction of customers in the market to take place. These firms might be more sensitive to customer needs when compared to their competitors; consequently, overall customer service would also be highly recognized by the customers. Therefore, if market orientation is strong, customer service will also be strong (Atuahene-Gima, 1995).

Firms which provide customers with high-quality service can achieve a high-market share as a result, (Bowen and Hedges, 1993) and can enjoy increased profits because of the high market share and cost premium (Philips et al., 1983). A high customer service level also has an effect on profits and provides other benefits to the firms (Greising, 1994; Rust et al., 1995; Zeithaml et al., 1996). Therefore, firms that have high market orientation should achieve a higher level of customer service because they can effectively listen to and respond to their customer needs by using methods such as intelligence generation, intelligence dissemination, and responsiveness in the market.

\section{Research model and methodology}

\subsection{Research model}

This research has two objectives: the first is to test whether innovation and market orientation have a direct, indirect, or a causal effect on the customer service levels within customs clearance firms; the second is to test the moderating effect of one independent variable in a relationship between a dependent variable and the other independent variable. This research model, which is based on prior research, shows a relationship between the two independent variables, innovation (which promotes collaboration among departments, work standardization, and process improvement) and market orientation (which induces 
intelligence generation, intelligence dissemination, and responsiveness), and one dependent variable, customer service, which displays customer focus, customer needs, customer response, and flexibility.

The analysis process is as follows. First, this research ascertains three relations. One is that innovation has an effect on market orientation. Another is that market orientation has an effect on customer service. The third is that innovation has an effect on customer service. This research also ascertains three relationships. One is that market orientation has an effect on innovation. Another is that innovation has an effect on customer service. And the third is that market orientation has an effect on customer service. This research suggests these implications by comparing the two analyses.

Secondly, this research carries out a moderating effect analysis, which retests the interactive effect between the variables in order to represent the analytical process of the causal effect. This analysis can ascertain whether market orientation enhances the relationship between innovation and customer service and if innovation enhances the relationship between market orientation and customer service, thereby following the results of the causal effects which represent a precedent condition in a moderated regression analysis. The research models are as follows in Figure 1 and Figure 2.

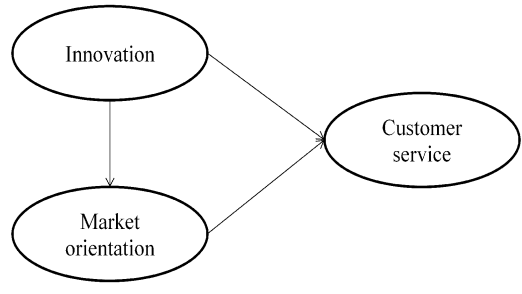

Figure 1.

Research model I

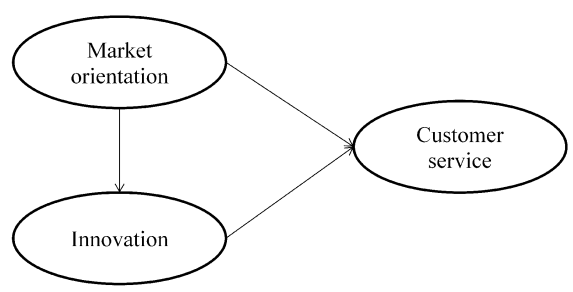

Figure 2.

Research model II

\subsection{Research hypotheses}

The relationship between the variables was checked in the literature review and the hypotheses are as follows:

H. 1 Innovation has a positive effect on market orientation.

H. 2 Market orientation has a positive effect on customer service.

H. 3 Innovation has a positive effect on customer service.

H. 4 Market orientation has a positive effect on innovation.

H. 5 Innovation has a positive effect on customer service. (This is the same as H. 3 ) 
H. 6 Market orientation has a positive effect on customer service. (This is the same as H. 2)

H. 7 Market orientation enhances the relationship between innovation and customer service.

H. 7-1 Intelligence generation enhances the relationship between innovation and customer

focus.

H. 7-2 Intelligence dissemination enhances the relationship between innovation and customer focus.

H. 7-3 Responsiveness enhances the relationship between innovation and customer focus.

H. 7-4 Intelligence generation enhances the relationship between innovation and customer needs.

H. 7-5 Intelligence dissemination enhances the relationship between innovation and customer needs.

H. 7-6 Responsiveness enhances the relationship between innovation and customer needs.

H. 7-7 Intelligence generation enhances the relationship between innovation and customer response.

H. 7-8 Intelligence dissemination enhances the relationship between innovation and customer response.

H. 7-9 Responsiveness enhances the relationship between innovation and customer response.

H. 7-10 Intelligence generation enhances the relationship between innovation and flexibility.

H. 7-11 Intelligence dissemination enhances the relationship between innovation and flexibility.

H. 7-12 Responsiveness enhances the relationship between innovation and flexibility.

\subsection{Research methodology}

\subsubsection{Measurement of variables}

This research suggests conceptual definitions and operational definitions of variables through prior research. Innovation implies the reliance on innovating internally in a firm's 
logistics processes in order to satisfy the customers' needs (Bowersox et al., 2002). Innovation can be divided into collaboration among departments, work standardization, and process improvement (Stank et al., 2001/2002). Market orientation means that firms should respond to customers' wishes better than their competitors do and that they strive to predict future changes in customers' wishes (Yoon and Bae, 2006). Market orientation can be divided into intelligence generation, intelligence dissemination, and responsiveness. Customer service can be explained as the ability to structure differentiation in order to attract customers' attention (Parasuraman et al., 1994; Stank et al., 2001/2002; Zeithaml et al., 1988).

\subsubsection{Sampling and methods of data collection}

The research population was customs brokers, incorporated customs clearance firms, and customs clearance service providers (this research uses the terminology for customs clearance firms in all of these areas). The sample frame was the membership list for the Korean Customs Brokers Association. The objective of the survey was to include all of the components related to this population because the population represented about a thousand firms. Questionnaires were sent to the members. Management department staff answered the questionnaires because they are accustomed to the business practices and also understand the characteristics of the customs clearance policy thoroughly.

The survey was performed by making personal visits to the company premises. The survey was performed from July 2011 to September 2011 and one hundred fifteen questionnaires were collected in the survey. One hundred twelve questionnaires were used in the analysis, and three questionnaires were deleted because they were not relevant.

\subsubsection{Methods of analysis}

This research used several analytical methods for testing the hypotheses. First, reliability was checked by using Cronbach's alpha coefficient, and an exploratory factor analysis and a confirmatory factory analysis were used to ascertain validity. Second, a causal link between the variables was tested with an analysis of the structural equation model. Third, a moderating effect was verified by using a moderated regression analysis. 


\section{The results of the empirical test}

\subsection{General characteristics of the responding firms}

This research analyzes the relationships between the variables in the 112 data. The annual turnover of the responding firms is as follows in Table 1.

\section{Table 1.}

Annual turnover of the responding firms (Unit: US\$100,000)

\begin{tabular}{|c|c|c|c|c|c|c|c|c|}
\hline Division & $\begin{array}{c}\text { Less } \\
\text { than 2 }\end{array}$ & $2-3$ & $3-5$ & $5-7$ & $7-10$ & $\begin{array}{c}\text { More } \\
\text { than 10 }\end{array}$ & $\begin{array}{c}\text { No } \\
\text { answer }\end{array}$ & total \\
\hline Frequency & 13 & 13 & 13 & 9 & 12 & 9 & 43 & 112 \\
\hline Ratio (\%) & 11.6 & 11.6 & 11.6 & 8.0 & 10.8 & 8.0 & 38.4 & 100 \\
\hline
\end{tabular}

The scale of the firms involved was measured by their annual turnover and there were 39 firms which recorded less than US\$500,000 (34.8\%). 43 (38.4\%) of the firms chose not to answer this question. They treated it as strictly confidential on the account that it is secret information which is related to business strategy. In particular, it appears that the firms did not want to release their annual turnover because it is directly connected to their customers. There are only 9 firms $(8.0 \%)$ which earned more than a million dollars. This finding means that most of these firms are small enterprises. Customs clearance firms do not need fixed assets in their characteristics. Their main job is to perform clearance on the behalf of shippers or consignees and they use expert systems which are based on computer programs. Also, they provide customers with additional services, such as the consolidation of goods, inspections, packing, and inland transportation. Therefore, these firms could be regarded as providing services on the basis of human resources.

There were two objectives in a correlation analysis: the first was to ascertain the overlapping measurement of the variables by checking the coefficients between the independent variables, while the second objective was to verify the relationships between the independent variables and the dependent variables. The results of this analysis are as follows in Table 2. 
Table 2.

The results of the correlation analysis

\begin{tabular}{|c|c|c|c|c|c|c|c|c|c|c|c|c|}
\hline variables & ave & S.D. & col & wor & pro & gen & dis & res & fle & foc & nee & rpe \\
\hline col & 4.898 & 1.288 & 1.000 & & & & & & & & & \\
\hline wor & 4.218 & 1.624 & 0.473 & 1.000 & & & & & & & & \\
\hline pro & 4.541 & 1.415 & 0.568 & 0.635 & 1.000 & & & & & & & \\
\hline gen & 5.067 & 1.122 & 0.684 & 0.313 & 0.480 & 1.000 & & & & & & \\
\hline dis & 4.571 & 1.452 & 0.584 & 0.485 & 0.817 & 0.525 & 1.000 & & & & & \\
\hline res & 5.187 & 1.269 & 0.581 & 0.216 & 0.551 & 0.568 & 0.623 & 1.000 & & & & \\
\hline fle & 5.076 & 1.182 & 0.554 & 0.227 & 0.573 & 0.496 & 0.507 & 0.740 & 1.000 & & & \\
\hline foc & 4.598 & 1.303 & 0.400 & 0.483 & 0.627 & 0.292 & 0.600 & 0.475 & 0.552 & 1.000 & & \\
\hline nee & 4.926 & 1.225 & 0.568 & 0.325 & 0.654 & 0.503 & 0.692 & 0.732 & 0.769 & 0.663 & 1.000 & \\
\hline rpe & 5.142 & 1.331 & 0.444 & 0.221 & 0.392 & 0.384 & 0.387 & 0.640 & 0.634 & 0.554 & 0.613 & 1.000 \\
\hline
\end{tabular}

* ave: average, S.D.: standard deviation, col: the collaboration among departments, wor: work standardization, pro: process imporvement, gen: intelligence generation, dis: intelligence dissemination, res: responsiveness, fle: flexibility, foc: customer focus, nee: customer needs, rps: response

As shown in the results, all of the coefficients were supported in the 5\% range, so it is possible to doubt the multicollinearity between the independent variables. This finding can be checked by finding the coefficient of MAX-VIF and tolerance. The relationship between the independent variables and the dependent variables shows that the findings are accurate.

Table 3.

The results of the multicollinearity test between the independent variables

\begin{tabular}{|c|c|c|c|c|}
\hline Variables & MAX-VIF & tolerance & $\mathrm{F}$ & Adj R2 \\
\hline Process & 4.646 & 0.215 & \multirow{6}{*}{$34.445^{* * *}$} & \multirow{6}{*}{0.644} \\
\hline Standardization & 1.908 & 0.524 & & \\
\hline Collaboration & 2.468 & 0.405 & & \\
\hline Generation & 2.077 & 0.482 & & \\
\hline Dissemination & 3.928 & 0.255 & & \\
\hline Responsiveness & 2.012 & 0.497 & & \\
\hline
\end{tabular}

$* * *: \mathrm{p}<0.01, * *: \mathrm{p}<0.05, *: \mathrm{p}<0.1$

Multicollinearity has two criteria, such as the MAX-VIF and the tolerance. There are no problems if the former coefficient is found to be less than 10 and if the latter coefficient is found to be over 0.1. As shown in Table 3, there are no problems with multicollinearity. 


\subsection{Reliability and validity}

This research verifies the reliability and validity before testing the hypotheses. Reliability is measured by using Cronbach's alpha coefficient proposed by Nunnally (1978), if the coefficient is over 0.6 , there is no issue. The validity is measured by using an exploratory factor analysis and a confirmatory factor analysis. Items are regarded as one factor if the factor loading coefficient is over 0.6. The results of the analysis related to innovation are as follows in Table 4.

\section{Table 4.}

The results of the exploratory factor analysis and the reliability of innovation

\begin{tabular}{|c|c|c|c|c|c|c|}
\hline \multirow{2}{*}{ items } & \multirow{2}{*}{$\begin{array}{l}\text { Factor } 1 \\
\text { (process) }\end{array}$} & \multirow{2}{*}{$\begin{array}{c}\text { Factor } 2 \\
\text { (standardization) }\end{array}$} & \multirow{2}{*}{$\begin{array}{c}\text { Factor } 3 \\
\text { (collaboration) }\end{array}$} & \multicolumn{2}{|c|}{ Variance of items } & \multirow{2}{*}{$\begin{array}{c}\text { Cronbach's } \\
\text { alpha }\end{array}$} \\
\hline & & & & before & after & \\
\hline Inn 1 & 0.180 & 0.100 & 0.887 & \multirow{3}{*}{5} & \multirow{3}{*}{3} & \multirow{3}{*}{0.856} \\
\hline Inn 2 & 0.203 & 0.248 & 0.807 & & & \\
\hline Inn 4 & 0.366 & 0.248 & 0.768 & & & \\
\hline Inn 6 & 0.144 & 0.830 & 0.212 & \multirow{2}{*}{5} & \multirow{2}{*}{2} & \multirow{2}{*}{0.830} \\
\hline Inn 8 & 0.460 & 0.752 & 0.172 & & & \\
\hline Inn11 & 0.756 & 0.298 & 0.361 & \multirow{5}{*}{5} & \multirow{5}{*}{5} & \multirow{5}{*}{0.927} \\
\hline Inn12 & 0.791 & 0.232 & 0.319 & & & \\
\hline Inn13 & 0.800 & 0.351 & 0.205 & & & \\
\hline Inn14 & 0.750 & 0.359 & 0.147 & & & \\
\hline Inn15 & 0.841 & 0.223 & 0.187 & & & \\
\hline Eigenvalue & 5.504 & 3.218 & 2.616 & - & - & - \\
\hline Variance (\%) & 36.694 & 21.50 & 17.437 & - & - & - \\
\hline
\end{tabular}

The results of the exploratory factor analysis for innovation are divided into 3 factors. Factor 1 is process improvement, which has 5 items, and Cronbach's alpha coefficient shows 0.927 . Factor 2 is work standardization, which has 2 items, and Cronbach's alpha coefficient shows 0.830 . Factor 3 is collaboration among departments, which has 3 items, and Cronbach's alpha coefficient shows 0.856 . Therefore, as shown in these results, there are no issues regarding the reliability and validity concerning innovation. 


\section{Table 5.}

The results of the exploratory factor analysis and the reliability of market orientation

\begin{tabular}{|c|c|c|c|c|c|c|}
\hline \multirow{2}{*}{ items } & \multirow{2}{*}{$\begin{array}{c}\text { Factor } 1 \\
\text { (responsiveness) }\end{array}$} & \multirow{2}{*}{$\begin{array}{c}\text { Factor } 2 \\
\text { (dissemination) }\end{array}$} & \multirow{2}{*}{$\begin{array}{c}\text { Factor } 3 \\
\text { (generation) }\end{array}$} & \multicolumn{2}{|c|}{ Variance of items } & \multirow{2}{*}{$\begin{array}{l}\text { Cronbach's } \\
\text { alpha }\end{array}$} \\
\hline & & & & before & after & \\
\hline Mar 1 & 0.210 & 0.316 & 0.691 & \multirow{2}{*}{5} & \multirow{2}{*}{2} & \multirow{2}{*}{0.639} \\
\hline Mar 5 & 0.296 & 0.113 & 0.769 & & & \\
\hline Mar 6 & 0.256 & 0.733 & 0.320 & \multirow{2}{*}{5} & \multirow{2}{*}{2} & \multirow{2}{*}{0.861} \\
\hline Mar 7 & 0.432 & 0.695 & 0.219 & & & \\
\hline Mar11 & 0.753 & 0.248 & 0.283 & \multirow{4}{*}{5} & \multirow{4}{*}{4} & \multirow{4}{*}{0.901} \\
\hline Mar13 & 0.838 & 0.174 & 0.112 & & & \\
\hline Mar14 & 0.782 & 0.224 & 0.371 & & & \\
\hline Mar15 & 0.771 & 0.054 & 0.450 & & & \\
\hline Eigenvalue & 4.343 & 3.994 & 2.297 & - & - & - \\
\hline Variance $(\%)$ & 28.953 & 26.629 & 15.313 & - & - & - \\
\hline
\end{tabular}

Table 5 shows the result of the exploratory factor analysis concerning market orientation. Market orientation is divided into 3 factors. Factor 1 is responsiveness, which has 4 items, and Cronbach's alpha coefficient shows 0.901. Factor 2 is intelligence dissemination, which has 2 items, and Cronbach's alpha coefficient shows 0.861 . Factor 3 is intelligence generation, which has 2 items, and Cronbach's alpha coefficient shows 0.639 . Therefore, there are no reliability or validity issues concerning market orientation. The customer service results are shown in Table 6. 
Clearance Firms in the International Logistics Processes: the Analyses of Direct, Indirect,

Causal Effects and Moderating Effects between Variables

\section{Table 6.}

The results of the exploratory factor analysis and the reliability of customer service

\begin{tabular}{|c|c|c|c|c|c|c|c|}
\hline \multirow{2}{*}{ items } & \multirow{2}{*}{$\begin{array}{c}\text { Factor } 1 \\
\text { (flexibility) }\end{array}$} & \multirow{2}{*}{$\begin{array}{c}\text { Factor } 2 \\
\text { (focus) }\end{array}$} & \multirow{2}{*}{$\begin{array}{l}\text { Factor } 3 \\
\text { (needs) }\end{array}$} & \multirow{2}{*}{$\begin{array}{l}\text { Factor } 4 \\
\text { (response) }\end{array}$} & \multicolumn{2}{|c|}{ Variance of items } & \multirow{2}{*}{$\begin{array}{c}\text { Cronbach's } \\
\text { alpha }\end{array}$} \\
\hline & & & & & before & after & \\
\hline Ser 1 & 0.264 & 0.787 & 0.094 & 0.289 & \multirow{3}{*}{4} & \multirow{3}{*}{3} & \multirow{3}{*}{0.881} \\
\hline Ser 2 & 0.211 & 0.842 & 0.239 & -0.017 & & & \\
\hline Ser 3 & 0.162 & 0.823 & 0.295 & 0.197 & & & \\
\hline Ser 5 & 0.232 & 0.488 & 0.664 & -0.025 & \multirow{5}{*}{5} & \multirow{5}{*}{5} & \multirow{5}{*}{0.917} \\
\hline Ser 6 & 0.360 & 0.139 & 0.753 & 0.320 & & & \\
\hline Ser 7 & 0.384 & 0.455 & 0.641 & 0.144 & & & \\
\hline Ser 8 & 0.454 & 0.343 & 0.700 & 0.120 & & & \\
\hline Ser 9 & 0.387 & 0.182 & 0.669 & 0.371 & & & \\
\hline Ser11 & 0.251 & 0.377 & 0.352 & 0.726 & \multirow{2}{*}{5} & \multirow{2}{*}{2} & \multirow{2}{*}{0.826} \\
\hline Ser12 & 0.403 & 0.190 & 0.077 & 0.786 & & & \\
\hline Ser15 & 0.778 & 0.201 & 0.330 & 0.000 & \multirow{5}{*}{5} & \multirow{5}{*}{5} & \multirow{5}{*}{0.929} \\
\hline Ser16 & 0.833 & 0.224 & 0.262 & 0.143 & & & \\
\hline Ser17 & 0.674 & 0.286 & 0.352 & 0.003 & & & \\
\hline Ser18 & 0.766 & 0.281 & 0.345 & 0.079 & & & \\
\hline Ser19 & 0.787 & 0.179 & 0.235 & 0.308 & & & \\
\hline $\begin{array}{c}\text { Eigenval } \\
\text { ue }\end{array}$ & 5.321 & 3.888 & 3.701 & 2.107 & - & - & - \\
\hline $\begin{array}{c}\text { Variance } \\
(\%)\end{array}$ & 28.007 & 20.461 & 19.478 & 11.092 & - & - & - \\
\hline
\end{tabular}

The results of the exploratory factor analysis are divided into 4 factors. Factor 1 is flexibility, which has 5 items, and Cronbach's alpha coefficient shows 0.929 . Factor 2 is customer focus, which has 3 items, and Cronbach's alpha coefficient shows 0.881 . Factor 3 is customer needs, which has 5 items, and Cronbach's alpha coefficient shows 0.917 . Factor 4 is customer response, which has 2 items, and Cronbach's alpha coefficient shows 0.826 . Therefore, there are no reliability or validity issues concerning customer service.

This research performs a confirmatory factor analysis in order to verify the validity of the data which is being sampled. This analysis is used in AMOS 18.0. There are no issues if a factor loading coefficient is over 0.5 and the C.R. is over 2.0. 


\section{Table7.}

The results of the confirmatory factor analysis

\begin{tabular}{|c|c|c|c|c|c|c|}
\hline \multicolumn{2}{|c|}{ variables } & estimate & S.E. & C.R. & P & Factor loading \\
\hline \multirow{4}{*}{ innovation } & collaboration & 0.720 & 0.089 & 8.122 & 0.000 & 0.828 \\
& standardization & 0.684 & 0.102 & 6.343 & 0.000 & 0.601 \\
& process & 1.000 & - & - & - & 1.043 \\
\hline \multirow{3}{*}{ Market } & generation & 0.760 & 0.117 & 6.490 & 0.000 & 0.632 \\
orientation & dissemination & 1.395 & 0.145 & 9.630 & 0.000 & 0.901 \\
& responsiveness & 1.000 & - & - & - & 0.733 \\
\hline \multirow{3}{*}{ Customer } & flexibility & 1.076 & 0.134 & 8.011 & 0.000 & 0.835 \\
service & focus & 1.046 & 0.147 & 7.128 & 0.000 & 0.729 \\
& needs & 1.225 & 0.142 & 8.607 & 0.000 & 0.914 \\
& response & 1.000 & - & - & - & 0.688 \\
\hline
\end{tabular}

As shown in Table 7, the fitness indices of the measuring model are as follows: chi-square $=33.961, \mathrm{df}=19, \mathrm{p}=0.019, \mathrm{Q}=1.787, \mathrm{GFI}=0.945, \mathrm{AGFI}=0.842, \mathrm{CFI}=$ $0.981, \mathrm{NFI}=0.959$, IFI $=0.981$, RMSEA $=0.084$. The measured items all show a C.R. over 2.0 and the factor loading coefficients are also all over 0.5. However, the null hypothesis is rejected because the characteristics of the sample firms are not the same as the characteristics of the population. Another reason that the hypothesis is rejected is because the RMSEA is over 0.08. However, the results from this research are meaningful because they can be applied to the sample firms.

\subsection{Testing the hypotheses}

This research tests the direct, indirect, and causal effects between variables and the moderating effect of one independent variable with the other independent variable and a dependent variable. The results of the analysis of the structural equation model which verifies the relationship between the variables is displayed in Table 8 . Table 9 displays the results of the direct, indirect, and causal effects. A direct effect is represented by estimates between variables; an indirect effect is an estimate which multiplies between an independent variable and a parameter by an estimate between a parameter and a dependent variable; and a causal effect is an estimate which equals the estimates between variables plus the coefficient of an indirect effect. 
Clearance Firms in the International Logistics Processes: the Analyses of Direct, Indirect,

Causal Effects and Moderating Effects between Variables

\section{Table 8.}

Testing the hypotheses

\begin{tabular}{|c|c|c|c|c|}
\hline Hypotheses & path & Estimate & C.R. & result \\
\hline H. 1 & innovation $\rightarrow$ market & 0.614 & 5.510 & supported \\
\hline H. 2 & market $\rightarrow$ service & 1.206 & 3.950 & supported \\
\hline H. 3 & innovation $\rightarrow$ service & -0.233 & -1.168 & Not supported \\
\hline
\end{tabular}

Table9.

The results of direct, indirect, and causal effects

\begin{tabular}{|c|c|c|c|}
\hline Path & Direct effect & Indirect effect & Causal effect \\
\hline innovation $\rightarrow$ market & 0.614 & - & 0.614 \\
\hline market $\rightarrow$ service & 1.206 & - & 1.206 \\
\hline innovation $\rightarrow$ service & -0.233 & 0.740 & 0.507 \\
\hline
\end{tabular}

Innovation has no effect on customer service in Table 8. However, innovation has a positive effect on customer service because of the indirect effect of market orientation in Table 9. As shown in the results, firms that want to enhance their customer service through innovation can enhance customer service as long as they perform market orientation at the same time. Therefore, market orientation enhances the relationship between innovation and customer service.

Table 10.

Testing the hypotheses

\begin{tabular}{|c|c|c|c|c|}
\hline Hypotheses & Path & Estimate & C.R. & result \\
\hline H. 4 & market $\rightarrow$ innovation & 1.224 & 9.233 & Supported \\
\hline H. 5 & innovation $\rightarrow$ service & -0.233 & -1.168 & Not supported \\
\hline H. 6 & market $\rightarrow$ service & 1.206 & 3.950 & supported \\
\hline
\end{tabular}

Table 11.

The results of direct, indirect, and causal effects

\begin{tabular}{|c|c|c|c|}
\hline Path & Direct effect & Indirect effect & Causal effect \\
\hline market $\rightarrow$ innovation & 1.224 & - & 1.224 \\
\hline innovation $\rightarrow$ service & -0.233 & - & -0.233 \\
\hline market $\rightarrow$ service & 1.206 & -0.285 & 0.507 \\
\hline
\end{tabular}


Market orientation has an effect on both innovation and customer service, but innovation has no effect on customer service. External information related to market-orientated activities can be used directly to enhance customer service. This information also has a direct influence on structuring efficient internal processes through innovative activities, such as the standardization of internal work processes, process improvement, and conducting collaborative work among departments. Consequently, customs clearance firms can enjoy a sustainable competitive advantage in the market if they improve innovative activities and customer service through market orientation. These firms can strategically use market information in order to restructure innovative processes and for improving customer service. As shown in Table 10 and Table 11, innovation does not influence the relationship between market orientation and customer service.

The next step is to test the effects of market orientation on the relationship between innovation and customer service. There are various methods which can be used for testing the moderating effect, but a moderated regression analysis is the best because of its strict criteria. A moderated regression model presumes 3 models. The model I: $y=a+b x+\varepsilon$, the model II: $y=a+b x+c z+\varepsilon$, and the model III: $y=a+b x+c z+d x z+\varepsilon$. The variables are as follows: $\mathrm{y}=$ dependant variable (customer service), $\mathrm{x}=$ independent variable (innovation), $\mathrm{z}=$ moderating variables (market orientation) and $\mathrm{xz}=$ added variables (innovation * market orientation).

Research on a moderating effect tests the effect of the moderating variables on the relationship between the independent and the dependant variables. A precedent condition for a moderated regression analysis is that the independent and moderating variables must have a causal link on the dependant variable. After verifying this condition, the research can then analyze whether market orientation as a moderating variable have a moderating effect on the relationship between innovation as an independent variable and customer service as a dependent variable. The process for this analysis is as follows: researchers compare model II with model III after an estimate of the three models. The R2 in model III must be higher than the R2 in model II and d must not be equal to 0 (zero). If these criteria are true, it means that market orientation has a moderating effect on the relationship between innovation and customer service. In this situation, the moderating variable is a pure moderating variable if $\mathrm{c}$ is 0 , but the variable is regarded as a quasi-moderating variable if $\mathrm{c}$ is not 0 , because there is a moderating effect. If there is no moderating effect, it appears that the R2 in model III is lower than the R2 in model II, and d is 0 . The results of this analysis are as follows in Table 12. 


\section{Table 12.}

The results of analyzing a moderating effect for market orientation on the relationship between innovation and flexibility

\begin{tabular}{|c|c|c|c|c|c|c|c|}
\hline \multirow{2}{*}{ variables } & \multicolumn{2}{|c|}{ Main effect } & $\begin{array}{l}\text { Moderated } \\
\text { effect }\end{array}$ & Main effect & $\begin{array}{c}\text { Moderated } \\
\text { effect }\end{array}$ & Main effect & $\begin{array}{l}\text { Moderated } \\
\text { effect }\end{array}$ \\
\hline & Model I & Model II & Model III & Model IV & Model V & Model VI & Model VII \\
\hline $\begin{array}{l}\text { Innovation } \\
\text { (A) }\end{array}$ & $\begin{array}{c}0.506 \\
(6.384 * * *)\end{array}$ & $\begin{array}{c}0.342 \\
(3.688 * * *)\end{array}$ & $\begin{array}{c}-0.558 \\
(-1.554) \\
\end{array}$ & $\begin{array}{c}0.326 \\
(2.673 * * *)\end{array}$ & $\begin{array}{c}-0.150 \\
(-0.599) \\
\end{array}$ & $\begin{array}{c}0.183 \\
(2.575 * * *)\end{array}$ & $\begin{array}{c}0.097 \\
(0.300) \\
\end{array}$ \\
\hline $\begin{array}{l}\text { Generation } \\
\text { (B) }\end{array}$ & & $\begin{array}{c}0.297 \\
(3.118 * * *)\end{array}$ & $\begin{array}{c}-0.481 \\
(-1.399) \\
\end{array}$ & & & & \\
\hline$A * B$ & & & $\begin{array}{c}0.173 \\
\left(2.590^{* *}\right)\end{array}$ & & & & \\
\hline $\begin{array}{l}\text { Dissemination } \\
\text { (C) }\end{array}$ & & & & $\begin{array}{c}0.180 \\
\left(1.929^{*}\right) \\
\end{array}$ & $\begin{array}{c}-0.228 \\
(-1.144) \\
\end{array}$ & & \\
\hline$A * C$ & & & & & $\begin{array}{c}0.170 \\
\left(1.991^{* *}\right)\end{array}$ & & \\
\hline $\begin{array}{c}\text { Responsivene } \\
\text { ss } \\
\text { (D) } \\
\end{array}$ & & & & & & $\begin{array}{c}0.599 \\
\left(8.795^{* * *}\right)\end{array}$ & $\begin{array}{c}0.593 \\
\left(2.355^{* *}\right)\end{array}$ \\
\hline$A^{*} \mathrm{D}$ & & & & & & & $\begin{array}{c}0.015 \\
(0.271) \\
\end{array}$ \\
\hline $\mathrm{R} 2$ & 0.270 & 0.330 & 0.369 & 0.294 & 0.319 & 0.573 & 0.574 \\
\hline Adj R2 & 0.264 & 0.318 & 0.352 & 0.282 & 0.301 & 0.565 & 0.562 \\
\hline
\end{tabular}

$* * *: \mathrm{p}<0.01, * *: \mathrm{p}<0.05, *: \mathrm{p}<0.1$

Foot note) generation: intelligence generation and dissemination: intelligence dissemination

According to the results, intelligence generation to innovation and flexibility shows an increased adj R2 in models II and III when compared with the R2 in model I. The variables independent, moderating, and additional variables also have a positive influence on the dependent variable. Therefore, intelligence generation has a moderating effect on the relationship between innovation and flexibility (H. 7-10 supported).

Another finding from this study shows that the moderating effect of intelligence dissemination to innovation and flexibility shows an increased adj R2 in models IV and V when compared with the R2 in model I. The variables independent, moderating, and additional variables have a positive influence on the dependent variable. Therefore, intelligence dissemination has a moderating effect on the relationship between innovation and flexibility (H. 7-11 supported).

These results are the same as the results of the causal effect. Innovation does not influence the relationship between market orientation and customer service. However, market orientation enhances the relationship between innovation and flexibility. Depending on the results, intelligence generation and dissemination can have a moderating effect on the relationship between innovation and flexibility. These results can be interpreted as follows: first, customs clearance firms can provide superior service to customers if they 
provide customers with flexible service and strive to grasp customer needs at the same time. Secondly, these firms can enhance service flexibility if they focus on innovation and if they share information acquired from the market with all of the other departments.

\section{Conclusion}

The goals of this research were twofold: the first goal was to ascertain whether innovation and market orientation had a direct, indirect, or causal effect on customer service, and the second was to ascertain whether market orientation had a moderating effect on the relationship between innovation and customer service. In order to achieve these goals, this research suggested the conceptual and the operational definitions of each variable through prior research. This research also explained the theoretical and practical implications and limitations of following these results.

The theoretical implications are as follows: first, innovation has a positive influence on market orientation. Customs clearance firms can achieve operational efficiency if they remove overlaps and inefficiencies in overall processes through process improvement, work standardization, and collaboration among departments. The efficient structuring of processes makes greater use of market intelligence because it is possible to use external information.

Secondly, market orientation has a positive influence on customer service. Market-oriented customs clearance firms should grasp customer needs and they should disseminate it in their internal processes. In this situation, these firms should make an effort to improve customer service by responding to customer needs. Customer service can be greatly enhanced from this effort. Therefore, these firms can enjoy a sustainable competitive advantage in the market.

Thirdly, market orientation has a positive influence on innovation. Customs clearance firms circulate external information regarding the internal processes through intelligence generation, intelligence dissemination, and responsiveness. Firms which grasp customer needs by using external information can improve their internal processes in order to effectively relate to their customers' needs. Therefore, it is possible for them to collaborate among departments in order to enhance work relationships and to improve the efficiency of the internal processes. For these reasons, companies can devise service processes according customers' wishes and can efficiently operate these processes thereafter.

H. 3 and H. 5 were not supported. One explanation for this is that through innovation, firms can efficiently use market intelligence to achieve internal efficiency and create 
efficient internal processes which thus attain customer needs. Therefore, market orientation enhances the relationship between innovation and customer service, which is the background of the moderating effect analysis.

Fourthly, market orientation has a moderating effect on the relationship between innovation and customer service. Customs clearance firms can quickly adapt to environmental changes through the improvement of sustainable processes. They may also achieve efficiency through standard work processes and can improve operational capability through collaboration among departments. These firms can also provide customers with superior customer service if they grasp their customers' needs and preferences, respond to these needs and preferences, and supply service to coincide with these needs and preferences. Therefore, firms can establish superior customer service processes and enhance their internal innovation through grasping sustainable change within the market.

The managerial implications are as follows. First, this research relates to the customer service which is provided by customs clearance firms and can be used to test the service that they provide. This research can also be used to suggest the methods for improving substantial services. Firms can evaluate their service by themselves, and they can subsequently enhance the strength of their services and improve the weakness that they uncover. Consequently, shippers and consignees can be supplied with high quality services by these firms. Therefore, customs clearance firms can enjoy sustainable comparative advantages in the market.

Secondly, innovation can be divided into process improvement, work standardization, and collaboration among the departments, which are concerned with the efficient management of the internal resources in a firm. Customs clearance firms can develop processes to remove overlaps and inefficiencies in the internal processes through estimating the efficient use of internal resources and suggesting methods of improvement regarding the inefficient use of resources at the same time.

Thirdly, market orientation is a method used by firms to grasp external information. Customs clearance firms can ascertain customer needs in the market, understand these needs within the firms, and use the needs to develop effective internal responses. Therefore, they can understand customer needs and ascertain the degree for achieving them in conformity by understanding market intelligence and ascertaining the degree of applying the market intelligence.

Fourthly, this research grasps the influencing factors of customer service, such as innovation and market orientation. The former is an internal-orientated strategy, and the latter is an external-orientated strategy. It is difficult to use both strategies at the same time. However, customs clearance firms can simultaneously pursue the ability for differentiation by using market intelligence and cost-saving through the achievement of internal efficiency 
because they are fairly small sized firms, according to Table 1 . This finding reflects the characteristics of customs clearance firms, and consequently, this research ascertains that they pursue a cost leadership strategy as well as a differentiation strategy at the same time.

Through these theoretical and managerial implications, this study suggests the basis of the research on precedent variables which have an influence on the customer service of customs clearance firms. In particular, the importance of these implications from this research can be acknowledged because this study addresses variables such as innovation and market orientation, which influences customer service by focusing on the firms.

Even though the implications of this research have been formulated, this study has several limitations. First, this study had difficulty correctly measuring innovation and market orientation because of the complexity of the composition and the variety of measurements. In particular, the conceptual and operational definitions, which came from the logistics research of the manufacturing firms, represented a limitation when using customs clearance firms as service firms. This limitation is a basic problem which comes from a lack of prior research related to logistics firms. However, this problem can be resolved by conducting additional subsequent research on the topic in order to reflect the characteristics of these types of firms.

Secondly, a large portion of the results related to moderating effects were not supported. There are various causes for this limitation, but the strict criteria of the moderated regression analysis are one of the main causes. However, analysis under the strict criteria is a necessary factor in this type of analysis. Therefore, researchers need to analyze the effects through other various analytical methods because using various types of methods could help resolve these problems.

\section{Acknowledgement}

This work was supported by Korea Sanhak Foundation in 2011 


\section{References}

Agarwal, S., M.K. Erramilli, and C.S. Dev(2003). Market Orientation and Performance in Service Firms: Role of Innovation. Journal of Service Marketing. 17(1): 68-82.

Atuahene-Gima, K(1995). An Exploratory Analysis of the Impact of Market Orientation on New Product Performance: A Contingency Approach. Journal of Product Innovation Management. 12(4): 275-293.

Beamon, B.M(1998). Supply Chain Design and Analysis: Models and Methods. International Journal of Production Economics. 55: 281-294.

Bowen, J.W. and R.B. Hedges(1993). Increasing Service Quality in Retail Banking. Journal of Retail Banking. 15: 21-28.

Bowersox, D.J., D.J. Closs and M.B. Cooper(2002). Supply Chain Logistics Management, McGraw Hill.

Caruana, A(1997). Market Orientation and Organizational Commitment in the Australian Public Sector. International Journal of Public Sector Management. 10(4): 294-303.

Daugherty, P.J., A.E. Ellinger and S.R. Clinton(1997). Information Technology Influence on World Class Logistics Capability. International Journal of Physical Distribution and Logistics Management. 27(1): 4-17.

Ellinger, A.E(2000). Improving Marketing/Logistics Cross-functional Collaboration in the Supply Chain. Industrial Marketing Management. 29: 85-96.

Esteban, A., A., Millan, A. Molina and D. Martin-Consuegra(2002). Market Orientation in Service: A Review and Analysis. European Journal of Marketing. 36(9/10): 1003-1021.

Gray, B., S., Matear, C. Boshoff and P. Matheson(1998). Developing Better Measure of Market Orientation. European Journal of Marketing. 32(9/10): 884-903.

Grawe, S.J., H. Chen and P.J. Daugherty(2009). The Relationship between Strategic Orientation, Service Innovation, and Performance. International Journal of Physical Distribution and Logistics Management. 39(4): 282-300.

Greising, D(1994). Quality: How to Make it Pay. Business Week. 8: 54-59.

Gunasekaran, A.C., C. Patel, and E. Tirtiroglu. 2001. Performance Measures and Metrics in a Supply Chain Environment. International Journal of Operations and Production Management. 21(1/2): 71-87.

Jaw, C., J.Y. Lo and Y.H. Lin(2010). The Determinants of New Service Development: Service Characteristics, Market Orientation, and Actualizing Innovation Effect. Technovation. 30: 265-277. 
Kim, K.S(2004). Analysis Structural Equation Modeling. Data Solution Inc.

Kohli, A.K. and B.J. Jaworski(1990). Market Orientation: The Construct, Research Propositions, and Managerial Implications. Journal of Marketing. 54: 1-18.

Lancaster, G. and H. van de Velden(2004). The Influence of Employee Characteristics in Market Orientation. International Journal of Banking Management. 22(5): 343-365.

Larson, P.D(1994). Am Empirical Study of Inter-organizational Functional Integration and Total Cost. Journal of Business Logistics. 15(1): 153-169.

Mollenkopf, D., A. Gibson and L. Ozanne(2000). The Integration of Marketing and Logistics Functions: An Empirical Examination of New Zealand Firms. Journal of Business Logistics. 21(2): 89-112.

Narasimhan, R. and S.W. Kim(2001). Information System Utilization Strategy for Supply Chain Integration. Journal of Business Logistics. 22(2): 51-75.

Narver, J.C. and S.F. Slater(1990). The Effect of a Market Orientation on Business Profitability. Journal of Marketing. 54: 20-35.

Nunnally, J(1978). Psychometric Theory. New York: McGraw-Hill.

Panayides, P.M(2004). Marketing in Asia-Pacific Logistics Companies: A Discreminent between Marketing Orientation and Performance. Asia Pacific Journal of Marketing and Logistics. 16(1): 42-68.

Parasuraman, A., V.A. Zeithaml and L.L. Berry(1994). Reassessment of Expectations as a Comparison Standard in Measuring Service Quality: Implications for Further Research. Journal of Marketing. 58: 111-124.

Philips, L.D., D.R. Chang, and R. Buzzell(1983). Product Quality, Cost Position and Business Performance: A Test of Some Key Hypotheses. Journal of Marketing. 47: 26-43.

Rust, R.T., A.J. Zahorik and T.L. Keiningham(1995). Return on Quality(ROQ): Making Service Quality Financially Accountable. Journal of Marketing. 59: 58-70.

Stank, T.P., P.J. Daugherty and A.E. Ellinger(1999). Marketing/Logistics Integration and Firm Performance. The Journal of Logistics Management. 10(1): 11-24.

Stank, T.P., S.B. Keller and D.J. Closs(2001/2002). Performance Benefits of Supply Chain Logistical Integration. Transportation Journal. 41(2/3): 32-46.

Storey, C. and F.M. Hull(2010). Service Development Success: A Contingency Approach by Knowledge Strategy. Journal of Service Management. 21(2): 140-161.

Yoon, K.W. and H.S. Bae(2006). The Effect of Relative Orientation on Customer Service Performance of Customers Clearance Firms. The Journal of Shipping and Logistics. 50: 157-180. 
Zeithaml, V.A., L.L. Berry and A. Parasuraman(1996). The Behavioral Consequences of Service Quality. Journal of Marketing. 60: 31-46.

Zeithaml, V.A., L.L. Berry and A. Parasuraman(1988). Communication and Control Processes in the Delivery of Service Quality. Journal of Marketing. 52: 35-48. 